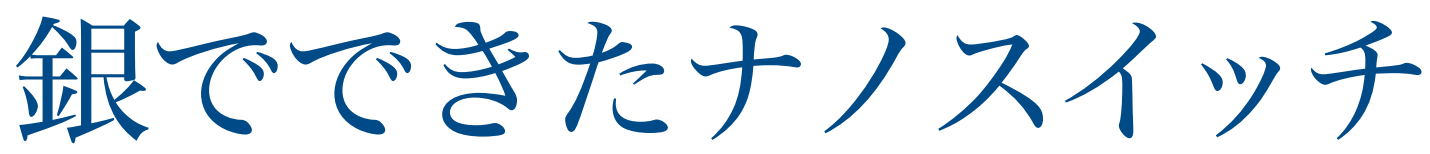

\title{
Silver nanoswitch
}

Jan van Ruitenbeek

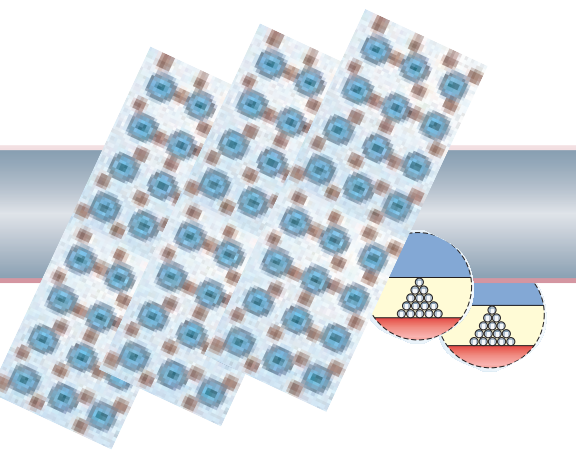

イオン伝導体は、センサー、燃料電池や普通の電池などいろいろな使い道がある。イオン伝導 体を基盤とするナノエレクトロニクス・デバイスは、今後シリコンにとって代わるのだろうか。 Nature Vol.433(21-22)/6 January 2005

ほとんどの電子機器はデジタルエレクトロニクスを基盤 とする。そのデジタルエレクトロニクスは、組織的な連 係で動作する数多くのスイッチを本質的に必要とする。 このため、既存のシリコン技術を凌駕するような信頼性 の高いスイッチング機構を見つけ、さらに小さく、強力 なエレクトロニクスを実現することを目指して、多くの研 究がなされている。理想的なスイッチとしては、原子サイ ズまでの縮小が望まれる。消費電力は小さく、メモリー

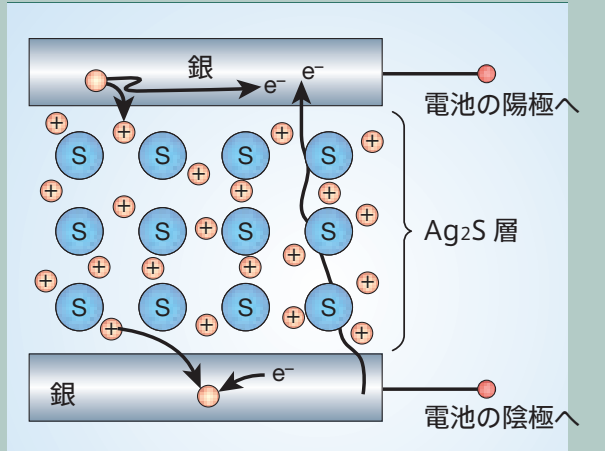

図 1 硫化銀 : 電子・イオン混合伝導体。 $\mathrm{Ag}_{2} \mathrm{~S}$ の上と下に $2 つ$ つ銀接点が接触し、電池につな がれている。電流の一部は電子によって運ばれ、 一部は硫化物を通って反対方向に拡散するプラ スの銀イオン (「十」を丸で囲んだもの) によっ て運ばれる。イオンは電極材料の酸化によって 陽極で補給され、同時に陰極で銀が還元され析 出する。
の読み出し書き込み操作のためにリード線 2 本のみを必 要とする。寺部一弥たちはこの理想スイッチに近づく発 明について述べている（原著論文は、Nature 2005 年 1 月 6 日号を参照のこと ) ${ }^{1}$ 。彼らは硫化銀の魅力的な性 質を利用した。この物質の電気伝導性は電子と銀イオン の双方が担う。その結果生まれたデバイスは高速のメモ リー操作だけでなく論理演算にも用いることができ、室 温で動作する。

ほとんどの固体では、原子は規則的な結晶格子中の 一定の位置に存在する。ところが、寺部らが使った固体 イオン伝導体では、一部のイオンが格子の中にいくつも の等価な位置をもつことができ、物質中をさまよい動く ことができる。図 1 は今回の関心の的となっている伝 導体 $\mathrm{Ag}_{2} \mathrm{~S}$ におけるこの様子を図解したものだ。硫化銀 を銀のリード線 2 本で電池に接続すると、硫化銀と銀の 陽極との界面に $\mathrm{Ag}^{+}$イオンが作られ、もう一方の電極で 還元される。つまりこの過程によって銀の輸送が起き、 プラスのリード線から銀が取り去られ、マイナスのリード 線に同量の銀が析出する。 $\mathrm{Ag}_{2} \mathrm{~S}$ は珍しい固体イオン伝 導体で、2つの変わつた特徵をもつ。 $\mathrm{Ag}_{2} \mathrm{~S}$ は室温で動 作し、電子だけでなくイオンも伝導するのだ。この両方 の特徴が、今回寺部たちが創り出したデバイスにとって 肝要なのである。

数年前、寺部たちは走査型トンネル顕微鏡 $(\mathrm{STM})$ を 用いた際に $\mathrm{Ag}_{2} \mathrm{~S}$ 結晶の表面にできたナノスケールの 銀のコブについて報告している ${ }^{2-4}$ 。この実験では底面に つけた銀の電極はプラチナの STM チップに対してプラス の電位を保持していた。チップから $\mathrm{Ag}_{2} \mathrm{~S}$ 表面へポテン シャル障壁を通り抜けた電子の一部は $\mathrm{Ag}^{+}$イオンを金属 
銀として析出させるために使われた。チップを表面から 一定の高さに維持すると、チップと試料の間に金属銀の 橋が形成された。この過程は電位を逆転させれば反対に なり、銀の橋は溶けて硫化物内に戻る。これがスイッチ の原理である。つまり、適切な符号の電圧を加えること で、接点をつないだり切ったりできる。近年、STMチッ プとサブストレートの間に多くのスイッチング機構が発見 されているが、個々のデバイスがそれ自身の STM を必 要とするために実用的な価值がほとんどなく、そういっ た研究はほとんど顧みられなかった。実用化するには、 $2 つ の$ 電極間のこのようなトンネル結合をより簡単な、 もつと再現性の高い方法で制御できる必要がある。

寺部たちはその巧みな解決法を見つけだした ${ }^{1}$ 。彼ら は必要とされるトンネル間隙をイオン伝導体自らが作り 出し、制御する性質を利用したのである。銀線面の上の $\mathrm{Ag}_{2} \mathrm{~S}$ 層が厚さ 1 ナノメートルの銀層を介して太いプラチ ナ線と接触している（図 2a）。そして、プラチナと銀の リード線は電圧源に接続され、上から下に電流が流孔る。 この電流にともなって硫化鉄を通って下へと向かう銀の 移動が起こり、数秒後に上面の銀層は消失し、プラチナ リード線との接触が切机る。こうしてデバイスは「オフ」 状態になり、動作可能な状態になる。印加電圧の極性を 逆転すると（図 2b)、局所的な銀の橋が即座に形成され、 プラチナと $\mathrm{Ag}_{2} \mathrm{~S}$ 間のギャップは再び閉じられ、スイッチ は「オン」状態に切り替わる。この過程にはほんの数個 の原子しか必要としないため、逆転と繰り返しが高速で できる。

さらに寺部たちは、振幅と持続時間が正確な短い電 圧パルスが印加できれば、デバイスのコンダクタンスを 1 量子単位程度まで小さくできることを観測した。この場 合、銀の橋はプラチナのリード線にちょうど 1 個の原子 が接触するまで上方に成長するように思われる（概論は 参考文献 5 を参照のこと)。「オン」と「オフ」状態を切 り替えるには $100 \mathrm{mV}$ より高い電圧を必要とする。メモ リービットの状態、つまりオンかオフかは、硫化銀の電 子伝導特性を利用してこの電圧より低い電圧で破壞する ことなく読み出すことができる。

$2 つ の$ 硫化銀スイッチと抵抗器、コンデンサーを組 み合わせて、寺部たちは基本的な論理演算 AND、OR、 NOT を行った。基本的には、より複雑な論理演算の実 行に必要なものはこれですべてである。しかし、入出 力を大きなデジタル回路内の別の論理ゲートと結合する と、この論理ゲートの効率は著しく落ちるだろう。この 問題を回避するには、ゲート信号を増幅する手段が必要 となる。でなければ、このデバイスの論理回路への応用 は限られたものになるだろう。著者らか観測した電圧の 増加に伴う複数のステップ、つまり量子化伝導度も注目

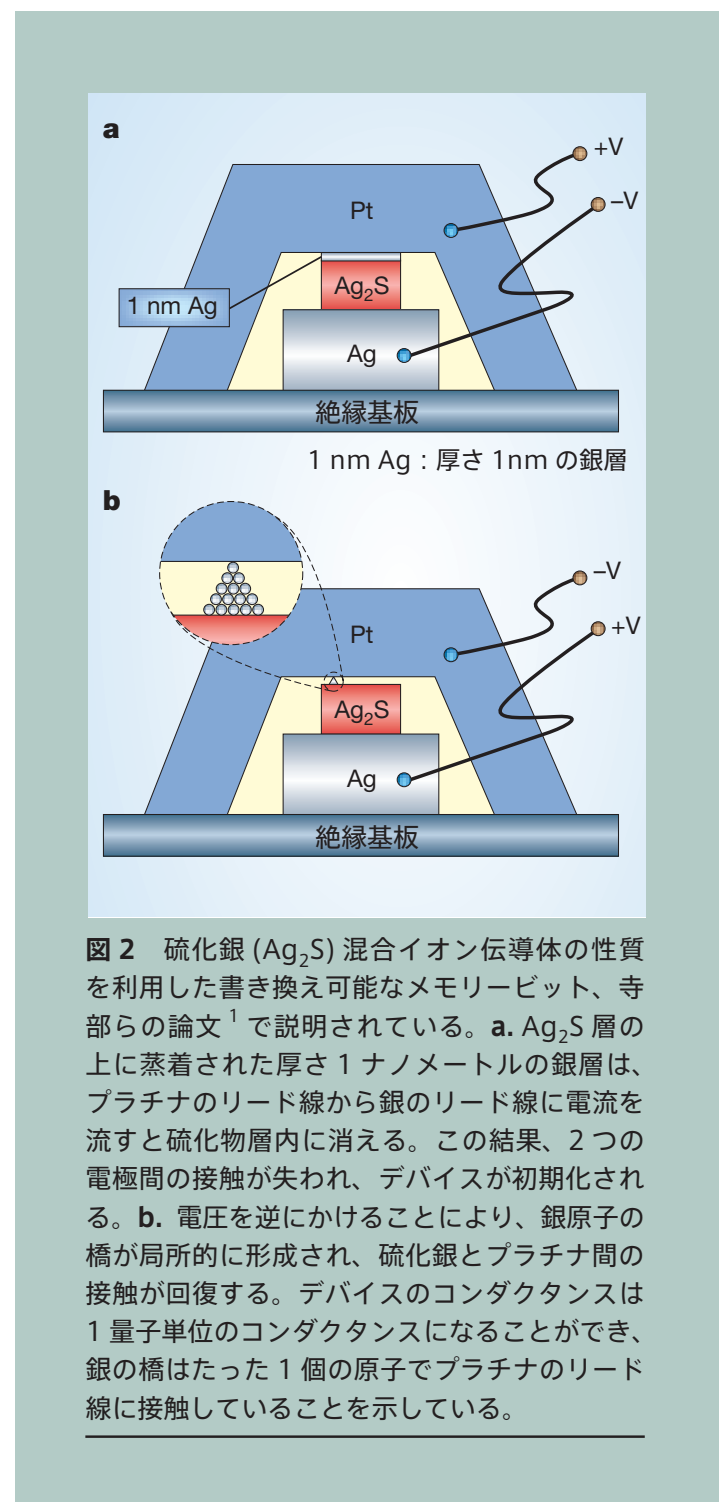

に值するが、再現性の乏しさからみて、実用性はおそら く十分とはいえない。

とはいえ、研究の主たる成果は極めて明快なもので、 ナノメートルサイズのアドレス可能なビットに縮小でき る。特許出願によって著者らが研究成果を保護されたの は賢明であった。

ライデン大学カマリン・オンネス研究所（オランダ）、 Jan van Ruitenbeek

1. Terabe, K., Hasegawa, T., Nakayama, T. \& Aono, M. Nature 433, 47-50 (2005).

2. Terabe, K., Hasegawa, T., Nakayama, T. \& Aono, M. RIKEN Rev. 37, 7-8 (2000).

3. Terabe, K., Hasegawa, T., Nakayama, T. \& Aono, M. Appl. Phys. Lett. 80, 4009-4011 (2002)

4. Terabe, K., Hasegawa, T., Nakayama, T. \& Aono, M. J. Appl. Phys. 91, 10110 10114 (2002).

5. Agraït, N., Levy Yeyati, A. \& van Ruitenbeek, J. M. Phys. Rep. 377, 81-279 (2003) 